UDC 629.735.052.5(045)

DOI:10.18372/1990-5548.66.15232

${ }^{1}$ Yu. M. Kemenyash,

${ }^{2}$ V. O. Gavrilenko

\title{
AUTOMATED SYSTEM FOR DISCHARGING FIRE-EXTINGUISHING LIQUID FROM A FIREFIGHTER'S PLANE
}

\author{
Aviation Computer-Integrated Complexes Department, National Aviation University, Kyiv, Ukraine \\ E-mails: ${ }^{1}$ lindysik999@gmail.com, ${ }^{2}$ vadymg.7@gmail.com
}

\begin{abstract}
The developed automated system of discharge of fire-extinguishing liquid from the firefighter's plane has a number of advantages, namely due to automation and more exact hit of fire-extinguishing liquid in a fire zone at zero visibility. It includes a sighting and navigation complex, which provides automatic determination of the fire zone, accurate sighting of liquid and a control system for opening tanks. The liquid discharge process is fully automated due to the implementation of the control algorithm for calculating the delay time, the discharge command taking into account the height, wind and ballistics of the discharged fluid, automating the decision on the number of open tanks. An algorithm for the process of discharging fire-extinguishing liquid for the rational use of aircraft in firefighting has been developed.
\end{abstract}

Index Terms - Sighting and navigation complex; liquid discharge; tanks.

\section{INTRODUCTION}

In Hundreds of thousands of square kilometers of forest land are burned on our planet every year. Forest fires cause great damage. In addition to destroying the environment, firewood destroys wood, animals and often people. In order to detect fires in a timely manner and prevent the spread of fires over large areas, special aviation fire brigades have been set up in many countries. [1]

Serious dangers to the environment, economy and population are fires in natural environments the so-called landscape fires. Depending on the place of origin, they are divided into forest, steppe, swamp, tundra, ghostly, savannah, steppe, reed, field and others.

In essence, landscape fire expands spontaneously during combustion, which leads to the destruction of forests, shrubs, peat reserves and various vegetation in its path. Elimination of natural fires often complic ates the difficult availability in the department, their remoteness from water sources, meteorological cond itions, strong winds, unstable personnel and resource $\mathrm{s}$ for water delivery.

Pets help find wallets from a variety of donations, all the most promising donation collection devices for use in the search for Australian goods, depending on how long it takes to find cats on pets.

For the application of forest fires will be found tanker aircraft (type MUL-76TD with a total capacity of onboard drainage devices 42 tons of water), AN-32P.

Having a number of historical advantages over ground forces and fire extinguishing means, fire aviation demands big expenses. Therefore, the question of assessing the effectiveness of An-32P aircraft and the feasibility of their involvement in the localization of natural fires is relevant.

Therefore, there is an urgent task of developing an automated system of discount fire extinguishing classification from the firefighter's plane, how to ensure the accuracy of the fire extinguishing technique to create the necessary front to stop the spread of fire.

\section{Problem Statement}

Extinguishing the fire from the plane is carried out at low altitude and in some places with zero visibility. When resetting manually, the statistics of the exact hit of the extinguishing liquid in the fire zone is about $30 \%$. Except for high-class crews, of which there are only a few in the world. Because you have to go to the second circle or in general to refuel. Additional fuel is consumed and the efficiency of such extinguishing becomes low and expensive.

Therefore, there is an urgent task of developing an automated system for discharging fire-extinguishing fluid from the aircraft firefighter AN-32P in order to improve tactical and technical characteristics. Improving the accuracy of the hit.

\section{PROBlem SOLUTION}

The design of aircraft tankers and the tactics of extinguishing fires differ in different countries, but the discharge of the fire extinguishing liquid in this case all over the world is still carried out mainly by the operator manually by pressing the drain button.

Taking into account the aircraft speed, this amounts to several seconds of its flight, during which 
the operator must timely press the liquid release button. Therefore, the task of developing an aiming device installed on board an aircraft carrier and providing automatic detection of a fire source and subsequent discharge of liquid onto it is very urgent.

The basis of the control part of the PNC are automatic control systems that provide stability, controllability, stabilization of flight coordinates (altitude, speed, roll angles, pitch, etc.). These tasks are solved by the autopilot part of the ACS, which includes the contours of stabilization and lateral movement of the aircraft.

Complexation of devices and systems. Complex application of means of navigation is the most rational use of all available superfluous information for maintenance of exact and safe flight in the conditions of a current meteorological situation. PNO of modern aircraft allows you to get navigation information in excess of the minimum amount needed to solve navigation problems. This makes it possible to use redundant information to improve the accuracy and reliability of the determination of navigation parameters.

The aircraft is equipped with 6 interconnected tanks. Moreover, the discharge of fire-extinguishing liquid can be carried out in different versions, as a single volley from all tanks together and sequentially from $4 x, 3 x, 2 x$ tanks, depending on the area of the fire and the target.

The automated system for discharging fireextinguishing liquid from a firefighter's aircraft includes: an on-board model of the IR sight that detects objects by temperature contrast, and an automatic control system for water tank flaps that receives a digital signal from the IR sight to turn on the required number of tanks.

The automated system for discharging fireextinguishing liquid from a firefighter's aircraft is the basis of the AANSC Pilot-Navigation Aiming Complex.

This complex is designed for automatic, semiautomatic or manual aircraft in simple and complex weather conditions (especially in heavy smoke from a fire), starting from the take-off stage; along the route, providing access to a given point and discharge of payload (landing or discharge of liquid during firefighting) with a given accuracy; as well as to return to the aerodrome and approach the landing in automatic (up to a height of 60 meters) or in director mode.

The main purpose of the aerobatic navigation sighting complex:

- solving aerobatic and navigational tasks;

- automation of the system of discharge of fireextinguishing liquid from the aircraft;
- optimization of the propulsion system, tank sash control system and other systems.

Distinctive features of ANC:

- availability of several, independent channels for obtaining navigation data;

- complexation of navigation systems based on the use of on-board digital computers (ODC);

- the use of special algorithms for information processing in ODC, which allow to ensure higher accuracy and reliability of navigation.

The close connection of navigation systems with the ACS allows you to automate the control of the aircraft at relatively complex and much longer stages of flight (flight on the route, aiming at the fire).

Pilot-navigation sighting complex taking into account the tank control system has the form of Fig. 1 [2].

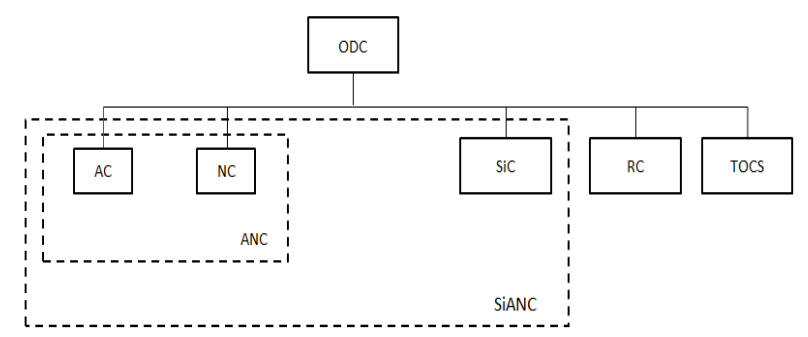

Fig. 1. Block diagram of the onboard automated complex: ODC is the onboard digital computer; ANC is the aerobatic navigation complex; $\mathrm{AC}$ is the aerobatic complex; $\mathrm{NC}$ is the navigation complex; $\mathrm{SiC}$ is the sighting complex; $\mathrm{RC}$ is the reconnaissance complex; $\mathrm{SiANC}$ is the sighting aerobatic and navigation complex; TOCS is the tank opening control system

The automated system of discharge of fireextinguishing liquid in the structure has an infrared sight IS from which the signal to the electronic decision-making device EDM it sends a signal to the computer. The computer also receives signals from ANC (road speed, air speed, true flight altitude), ballistic parameter of the discharged liquid and the delay time for discharging. Then the computer emits two signals. One in ACS to stabilize the height, and the second - the control system of the sash of the tank of the firefighter. Water tank sash control system that receives a digital signal from a computer to turn on the required number of tanks and operates automatically.

The block diagram of such an automated system for discharging fire-extinguishing liquid has the form of Fig. 2 [3].

To select the optimal mode of water discharge from the aircraft, it is necessary to create a model that allows to calculate the surface distribution of the discharged liquid according to the given input parameters, which takes into account the spatial and 
ground distribution of liquid depending on weather conditions (wind speed and direction) and discharge conditions, volume of liquid discharge, etc.).

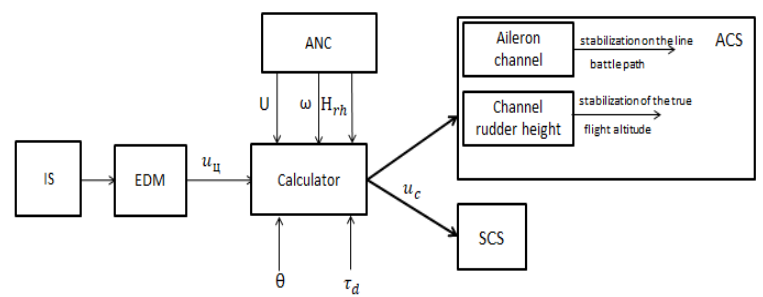

Fig. 2. Block diagram of the automated system of discharge of fire-extinguishing liquid: ACS is the automatic control system; EDM is the electronic decision maker; ANC is the aerobatic navigation complex; SCS is the sash control system; $U$ is the air speed; $\theta$ is the ballistic parameter of the discharged liquid; $\omega=V+U$ is the road speed; $H_{r h}$ is the true altitude (radio height); $A_{\omega}$ is the longitudinal removal of fluid; $\tau_{d}$ is the reset delay time

In determining the effect of different flight parameters on the specific characteristics of the ground distribution discharged from the aircraft, the following parameters are used Fig. 3 [4].

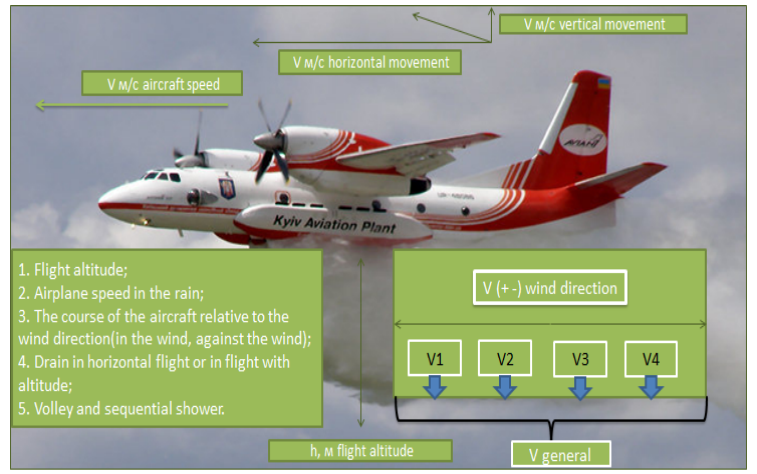

Fig. 3. Parameters of water discharged from the aircraft

The decision of exact hit of liquid in a fire zone should be based on the developed theory of bombing taking into account wind. You need to calculate the delay for the discharge of fluid [5].

If the horizontal range $\mathrm{l}_{0}$ detection of a fire will be a more longitudinal purpose $A_{\omega}$ discharge at point $B$ of the liquid, then, as a parameter that determines the time of its automatic discharge, you can use, for example, a time delay $\tau_{d}$ issuance of a reset command, which must be calculated from the moment of detection of foci at point $O$.

The delay time for the reset in the assumption of its instantaneous execution is calculated as

$$
\tau_{d}=\frac{\mathbf{l}_{0}-A_{\omega}}{\omega}>0 .
$$

The scheme of aiming when discharging the liquid has the form of Fig. 4.

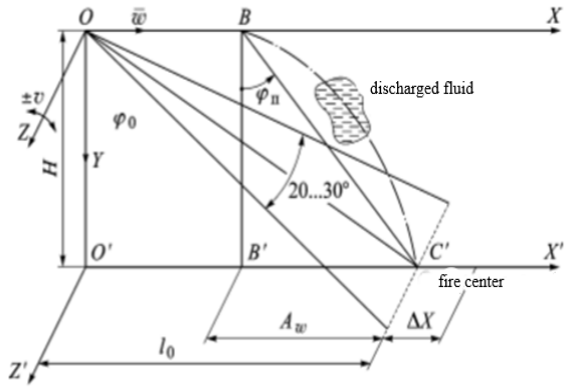

Fig. 4. Aiming scheme when discharging liquid

Here, the speed of the aircraft is defined as the algebraic sum of its air speed $V$ and wind speed $U$, and

$$
A_{\omega}=A_{v} \pm U T,
$$

where $A_{v}$ is the longitudinal include liquids in the absence of wind, and $T$ is the time of falling of liquid from height $H$ of flight of the plane. Since the counterflow reduces the value $A_{\omega}$ and $\omega$, then with such an event the plane at the fire center has a delay time $\tau_{d}$ will increase, which facilitates the work of the crew at the stage of withdrawal of aircraft into combat. In addition, to eliminate the longitudinal aiming error $\pm \Delta X$ due to random oscillations of the tank body around the $Z$ axis at the pitch angles $\pm v$, the sighting line of the $O C$ must be stabilized in space.

For the rational use of aircraft for firefighting it is necessary to develop an algorithm for the process of discharging fire extinguishing fluid. Therefore, the block diagram of the process of the automated system of discharge of fire-extinguishing liquid has the form of Fig. 5.

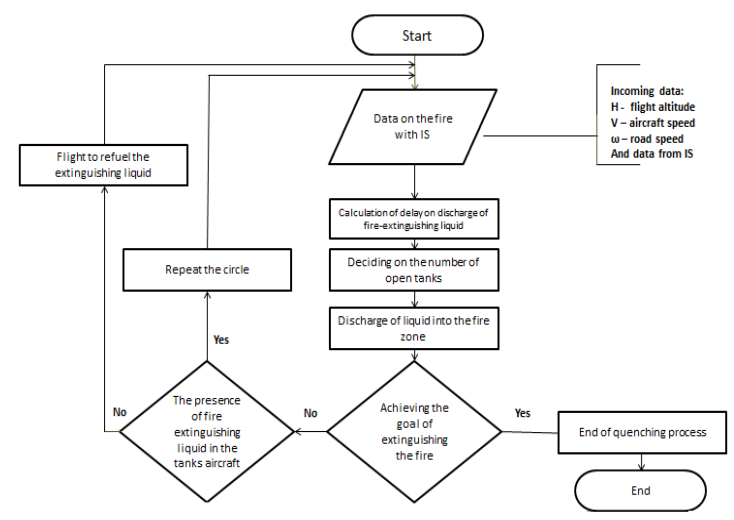

Fig. 5. Block diagram of the process of automated system for discharging fire extinguishing fluid

\section{CONCLUSIONS}

The developed automated system of discharge of fire-extinguishing liquid from the firefighter's plane has a number of advantages, namely due to 
automation and more exact hit of fire-extinguishing liquid in a fire zone at zero visibility. It includes a sighting and navigation system, which provides automatic determination of the fire zone, accurate sighting of liquid and a control system for opening tanks.

The liquid discharge process is fully automated due to the implementation of the control algorithm for calculating the delay time, the discharge command taking into account the height, wind and ballistics of the discharged fluid, automating the decision on the number of open tanks.

An algorithm for the process of discharging fireextinguishing liquid for the rational use of aircraft in firefighting has been developed.

The system expands the range of available tactical techniques when searching for a target, reaching the target, aiming and using weapons at ground targets. According to the manufacturer, the effectiveness of a strike with free-falling ammunition increases at least three times, due to an increase in the target detection range, its classification (identification), and an improvement in accuracy characteristics.

\section{REFERENCES}

[1] https://pidruchniki.com/16330826/bzhd/lisovi_to rfovi_pozhezhi

[2] V. M. Baluev, V. M. Gerasimov, and V. I. Kozmenko, ed. A. M. Krasnova, Aiming theory and sighting and navigation systems, collection of articles. Tasks. VVIA them. N. E. Zhukovsky. Moscow, 1990, 70 p.

[3] V. A. Bodner and M. S. Kozlov, Stabilization of aircraft and autopilots, Textbook. manual for aviation. universities, ed. Dr. tech. sciences prof. V. A. Bodner. Moscow: Oborongiz, 1961, 508 p.

[4] V. N. Masaev and Yu.V. Ovechnikov, "Achieving the required resetting the settings, the extinguishing agent from an airplane - amphibian Be-200ES for fire landscape fires using an algorithm of the mathematical model," Scientific and analytical journal "Siberian fire and rescue vestnik," no. 2, 2016, pp. 15-20.

[5] I. M. Ilyukhin, Automatic sight for forest fire aviation, Bulletin of MSTU named after N.E. Bauman. Ser. Instrumentation. 2009, pp. 105-112.

Received October 23, 2020.

Kemenyash Yuriy. Senior Teacher.

Aviation Computer-Integrated Complexes Department, National Aviation University, Kyiv, Ukraine.

Education: National Aviation University, Kyiv, Ukraine, (1996).

Research area: automation, navigation.

Publications: more than 30.

E-mail: lindysik999@gmail.com

GavrilenkoVadym. Master of Science.

Aviation Computer-Integrated Complexes Department, National Aviation University, Kyiv, Ukraine.

Research area: Automation, navigation.

E-mail: vadymg.7@gmail.com

Ю. М. Кеменяш, В. О. Гавриленко. Автоматизована система скидання вогнегасної рідини 3 літака пожежника

Розроблена автоматизована система скидання вогнегасної рідини з літака пожежника має ряд переваг, а саме за рахунок автоматизації та більш точного влучання вогнегасної рідини в зону пожежі при нульовій видимості. До неї входить прицільно-навігаційний комплекс, який забезпечує автоматичне визначення зони пожежі, точне прицільне скидання рідини та система керування відкриттям баків. Процес скидання рідини повністю автоматизований за рахунок реалізації керуючого алгоритму розрахунку часу затримки, команди на скидання 3 урахуванням висоти, вітру та балістики скинутої рідини, автоматизації прийняття рішення щодо кількості відкритих баків. Розроблено алгоритм процесу скидання вогнегасної рідини для раціонального використання авіаційної техніки при пожежогасінні.

Ключові слова: прицільно-навігаційний комплекс; скидання рідини; баки.

Кеменяш Юрій Михайлович. Старший викладач.

Кафедра авіаційних комп’ютерно-інтегрованих комплексів, Національний авіаційний університет, Київ, Україна.

Освіта: Національний авіаційний університет, Київ, Україна, (1996).

Напрям наукової діяльності: автоматизація, навігація.

Кількість публікацій: більше 30 наукових робіт.

E-mail: lindysik999@gmail.com

Гавриленко Вадим Олегович. Магістр.

Кафедра авіаційних комп'ютерно-інтегрованих комплексів, Національний авіаційний університет, Київ, Україна. 
Напрям наукової діяльності:автоматизація, навігація.

E-mail: vadymg.7@gmail.com

Ю. М. Кеменяш, В. О. Гавриленко. Автоматизированная система сброса огнетушащей жидкости с самолета пожарника

Разработанная автоматизированная система сброса огнетушащей жидкости с самолета пожарника имеет ряд преимуществ, а именно за счет автоматизации и более точного попадания огнетушащей жидкости в зону пожара при нулевой видимости. В нее входит прицельно-навигационный комплекс, обеспечивающий автоматическое определение зоны пожара, точный прицельный сброс жидкости и система управления открытием баков. Процесс сброса жидкости полностью автоматизирован за счет реализации управляющего алгоритма расчета времени задержки, команды на сброс с учетом высоты, ветра и баллистики сброшенной воды, автоматизации принятия решения относительно количества открытых баков. Разработан алгоритм процесса сброса огнетушащей жидкости для рационального использования авиационной техники при пожаротушении.

Ключевые слова: прицельно-навигационный комплекс; сброс жидкости; баки.

Кеменяш Юрий Михайлович. Старший преподаватель.

Кафедра авиационных компьютерно-интегрированных комплексов, Национальный авиационный университет, Киев, Украина.

Образование: Киевский авиационный университет, Киев, Украина, (1996).

Направление научной деятельности: автоматизация; робототехнический комплекс.

Количество публикаций: более 30 научных работ.

E-mail: lindysik999@gmail.com

ГавриленкоВадим Олегович. Магистр.

Кафедра авиационных компьютерно-интегрированных комплексов, Национальный авиационный университет, Киев, Украина.

Направление научной деятельности: автоматизация, навігація.

E-mail: vadymg.7@gmail.com 